\title{
Job prospects in the United States
}

from Richard Pearson

\section{With the United States' economic boom continuing, and the rate of job generation far outstripping that of other Western economies, what are the job prospects for life scientists and engineers?}

Projecting future employment levels is notoriously difficult, yet for occupations requiring many years of training and experience, insights into future employment patterns and imbalances can show where significant adjustments might be needed in labour market and training policies. Any forecasts, however, can only be as good as the assumptions on which they are based, and these need to involve assessments of future levels of economic and investment activity, and technological and productivity changes.

Although scientists, engineers and technicians account for only a small fraction of the US workforce (less than 5 per cent), they have a disproportionate role in economic growth, technical innovation and national security and are a key area of concern. A key role for the governmental National Science Foundation (NSF) in Washington is to provide information on the availability, both current and projected, of such scientific and technical resources in the United States. A recent NSF study looks at the ability of the labour force to fuel the expected 45 per cent increase in defence expenditure over the period 1982 to 1987 (see Table 1). A series of scenarios was used, looking at the implications of high and low growth rates in Gross

\begin{tabular}{|c|c|c|c|}
\hline Table 1 & $\begin{array}{l}\text { d US } \\
\text { ae year }\end{array}$ & $\begin{array}{l}\text { loyment } \\
82-87\end{array}$ & anges \\
\hline \multicolumn{4}{|c|}{ Employment (thousands) } \\
\hline & 1982 & $\begin{array}{l}1987 \text { (low } \\
\text { growth) }\end{array}$ & $\begin{array}{c}1987 \text { (higl } \\
\text { growth) }\end{array}$ \\
\hline $\begin{array}{l}\text { Computer } \\
\text { scientists }\end{array}$ & 219 & 287 & 303 \\
\hline $\begin{array}{l}\text { Other } \\
\text { scientists }\end{array}$ & 508 & 556 & 585 \\
\hline Engineers & 1,140 & 1,296 & 1,423 \\
\hline Technicians & 1,468 & 1,649 & 1,760 \\
\hline
\end{tabular}

Values for 1982 are 'actual', and those for 1987 are projected. Source: Projected Response of the Science Engineering, and Technician Labor Market to Defense and Non-Defense Needs: 1982-87 (National Science Foundation, Washington, 1984).

Domestic Product between 2 and 4 per cent per year, and of two defence expenditure scenarios averaging 3 and 8 per cent per year growth.

Growth in demand for scientific engineering and technician (SET) manpower is expected to grow by between 2.6 and 4.1 per cent per year, a rate of growth higher than for employment generally (up 1-2.4 per cent per year). This increasing demand is driven not only by the strong performance of high technology industries, with their high concentrations of SET manpower, but more importantly by the diffusion of technology throughout the economy, which has led to a significant shift in staffing patterns towards SET employment. Interestingly, although each scenario focuses on rather different sets of assumptions, the projected range of SET requirements is rather more restricted, never varying by more than 5 per cent from the average 1987 projected value in any of the major occupational categories (Table 1). This is in part because SET manpower is only a small proportion of all jobs in the economy but also because productivity increases at a much faster rate under the high growth scenario, with the productivity gains counterbalancing the employment impact of economic growth which in turn reduces the need for additional SET manpower.

There were nearly 750,000 university degree level science jobs in the US economy in 1982 and this figure was expected to grow by between 116,000 ( 3 per cent per year) and 161,000 (4.1 per cent per year) jobs over the period to 1987 . Both these figures represent a slow-down in the 8.7 per cent average annual growth rate over the period 1977-1982. The key determinants of these growth patterns are shown to be primarily economy-related, with the key driving forces for increased scientific jobs being the service sectors, particularly research and development laboratories, consulting firms and computer establishments.

The engine of this growth in science jobs seems to be the computer, with computer systems analysts, an occupation first recognized officially in the 1970 census, accounting for about 300,000 people in 1987 , regardless of the scenario followed, with half of them employed in business services. The growth in these jobs will average about 6 per cent per year, the net growth being $70,000-85,000$ jobs over the five years. Computer specialists are expected to dominate science jobs in 1987 , increasing their share over the period from 34 to 55 per cent, with psychologists, chemists and mathematicians being the other largest groups.

Of the physical sciences, physics has the fastest growth at 1.4 to 3 per cent per year with growth for chemists being rather lower, at 1.5-2.5 per cent, a figure similar to that for geologists. Mathematical science is projected to have rather faster growth at 2.2-3.5 per cent per year but the total job gain will only be $5,000-10,000$ jobs overall. In the life sciences, agricultural jobs barely keep pace with overall employment growth, and while the number of jobs for biological scientists will grow rather faster, the total job gain will be only about 5,000-10,000 extra jobs.

By way of contrast, engineering shows an overall growth of between 2.6 and 4.5 per cent with aeronautical/astronautical employment rising by a massive 5.9-11.1 per cent per year, a gain of $22,000-45,000$ jobs. Electronics is the other major growth occupation, and although it shows rather less spectacular growth of between 3.9 and 5.1 per cent, the expected gains of between 69,000 and 94,000 jobs match the absolute growth in jobs for computer systems analysts.

As well as considering possible demand, NSF also makes corresponding supply projections, taking account of such factors as new entrants to the labour force, occupational mobility, immigration, and deaths and retirements. The model projects that supply will exceed demand under all the scenarios for all science occupations; for example, there could be three people seeking every job. However, significant shortages are indicated for aeronautical/astronautical engineers and electronic engineers, together with particularly large shortages in the computer speciality fields. These projections, however, assume no major forms of labour force adjustment such as increased salaries, reduced hiring standards, significant mobility from other occupations or increased immigration. One particular concern is the possibility that industry may be so attractive that the universities will be unable to attract enough talented people for research.

Labour market adjustments are expected to alleviate the likely level and impact of shortages in the above disciplines, and also mitigate the size of surpluses. But NSF's main concern is that the larger the adjustment needed, the greater the impact on and likely lowering of the quality of the workforce. This could induce productivity and quality losses in the short term, while hindering longer-term supply of skilled manpower if the academic sector cannot retain graduate students or its existing faculty. Already many specialists in information technology are leaving academic posts for industry. However, for many of those seeking a science-linked job, employment prospects are declining and may continue to deteriorate for the next few years. Occupational mobility and retraining will then become higher priorities for the individual seeking secure employment.

Richard Pearson is at the Institute of Manpower Studies, Mantell Building, University of Sussex, Brighton BNI 9RF, UK. 